\title{
Effect of light exposure on secondary metabolites production of an endophytic fungus Arthrinium rasikravindrae and its antioxidant and anticancer activities
}

\author{
ANDITA ELTIVITASARI ${ }^{1}$, RAHMAWATI ${ }^{1}$, BAIQ MAYLINDA GEMANTARI ${ }^{1}$, FITRA ROMADHONSYAH ${ }^{1}$, \\ ARIEF NURROCHMAD ${ }^{2}$, SUBAGUS WAHYUONO ${ }^{3}$, PUJI ASTUTI ${ }^{3, \bullet}$ \\ ${ }^{1}$ Faculty of Pharmacy, Universitas Gadjah Mada. Jl. Sekip Utara, Sleman 55281, Yogyakarta, Indonesia \\ ${ }^{2}$ Department of Pharmacology and Clinical Pharmacy, Faculty of Pharmacy, Universitas Gadjah Mada. Jl. Sekip Utara, Sleman 55281, Yogyakarta, \\ Indonesia \\ ${ }^{3}$ Department of Pharmaceutical Biology, Faculty of Pharmacy, Universitas Gadjah Mada. Jl. Sekip Utara, Sleman 55281, Yogyakarta, Indonesia \\ Tel./fax.: +62-274-543120, ’email: puji_astuti@ugm.ac.id
}

Manuscript received: 3 April 2021. Revision accepted: 11 May 2021

\begin{abstract}
Eltivitasari A, Rahmawati, Gemantari BM, Romadhonsyah F, Nurrochmad A, Wahyuono S, Astuti P. 2021. Effect of light exposure on secondary metabolites production of an endophytic fungus Arthrinium rasikravindrae and its antioxidant and anticancer activities. Biodiversitas 22: 3156-3163. Endophytic microorganisms are one of the promising sources in producing bioactive compounds, to be developed for new drug candidates. They are found to have the ability to generate the same compounds as their host plant. Metabolite producing capacity of the endophytes is known to be affected by light exposure during fermentation process. This study focused on an endophytic fungus Arthrinium rasikravindrae isolated from Coleus amboinicus stem to reveal out its metabolite profiles due to light exposure as well as its bioactivity consequences. A. rasikravindrae was cultured on potato dextrose broth medium for 14 days and fermented in dark and exposed to natural light. Metabolite profiling was performed using TLC and GC-MS analysis. The activities were observed using DPPH assay for antioxidant and MTT assay for cytotoxicity potential. The results showed that $A$. rasikravindrae ethyl acetate extract produced during dark and exposed to light fermentation conditions contained different compounds but there was some which showed similarity with their host plant. Methyl octadec-9-enoate was found in all fermentation conditions as well as in $C$. amboinicus stem extract. Besides methyl octadec-9-enoate, methyl palmitate was also found present in both $A$. rasikravindrae extract fermented exposed to light and its host plant. The antioxidant activity of extract generated from dark fermentation condition was better as compared to that exposed to light with $\mathrm{IC}_{50}$ value of $66.36 \pm 0.53$ vs $556.92 \pm 34.37 \mu \mathrm{g} / \mathrm{mL}$. However, cytotoxic activity screening against several cancer cell lines exhibited opposing results in which extract from light-exposed fermentation resulted in better cytotoxic activity (IC50 value of $291.40 \pm 2.34 \mu \mathrm{g} / \mathrm{mL}$ on WiDr, $336.80 \pm 5.05 \mu \mathrm{g} / \mathrm{mL}$ on T47D, and $404.73 \pm 3.46 \mu \mathrm{g} / \mathrm{mL} \mathrm{on}$ Hela cell lines). Extract obtained from dark fermentation condition showed IC 50 value of more than $500 \mu \mathrm{g} / \mathrm{mL}$ in all tested cancer cell lines. Preliminary examination on cytotoxic activity against WiDR cells suggested that the extract from light-exposed fermentation might induce cell death through mechanisms involving cell cycle arrest.
\end{abstract}

Keywords: Antioxidant, Arthrinium rasikravindrae, cytotoxic, endophytic fungus, light, metabolites profiles

Abbreviations: DPPH: 2,2-diphenyl-1-picrylhydrazyl; GC-MS: Gas Chromatography-Mass Spectrometry; MTT: 3-(4,5-dimethylthiazol-2-yl)-2,5-di-phenyltetrazolium bromide); TLC: Thin Layer Chromatography; PDA: Potato Dextrose Agar; PDB :Potato Dextrose Broth; RPMI: Roswell Park Memorial Institute; DMEM: Dulbecco's Modified Eagle Medium; DMSO: Dimethyl Sulfoxide

\section{INTRODUCTION}

Coleus amboinicus is a member of the family of Lamiaceae, known to contain many clinically useful bioactive compounds such as flavonoids, alkaloids, tannins, triterpenoids and saponins (Damanik et al. 2017; Aisyah et al. 2020). This medicinal plant in Indonesia is called torbangun and has been traditionally used by Bataknese as a stimulant for breast milk (a lactagogue) (Damanik 2009). C. amboinicus leaves were described to have pharmacological properties such as antimicrobial, antimutagenic, antitumorigenic, antiepileptic, urolithiasis, radioprotective, and neuropharmacological activities (Bhatt et al. 2013). It was reported that ethyl acetate extract from $C$. amboinicus leaves had antioxidant and cytotoxic activity against $\mathrm{HeLa}$,
T47D and MCF7 cells (Hasibuan et al. 2019). It was also reported that the stem extract of Plectranthus amboinicus was rich in antioxidants and exhibiting anti-platelet aggregation, antibacterial activity, as well as antiproliferative effects on Caco-2, HCT-15, and MCF-7 cancer cells (Bhatt et al. 2013). Major phenolics compounds reported to be found in stem extracts of $C$. amboinicus are rosmarinic acid, caffeic acid, rutin, gallic acid, quercetin, and p-coumaric acid (Bhatt et al. 2013). In addition, thymol, carvacrol, 1,8-cineole, p-cymene, spathulenol and terpinen-4-ol were shown to be the main constituents of $C$. amboinicus leaf essential oil (Arumugam et al. 2016). Some of these components (carvacrol, thymol and 1,8-cineole) were functioned as antioxidant and also used for cancer therapy (Pinheiro et al. 2015; Quiroga et al. 
2015; Mahran et al. 2019). It has been observed that compounds having antioxidant properties are capable of preventing degenerative diseases (Sinha and Dabla 2015; SA Rifki et al. 2019). Additionally, some reports are available which revealed that antioxidant properties are related to the mechanism to induce apoptosis, one of the strategies in killing cancer cells (Salganik 2001; Rzepczynska et al. 2011).

Endophytic fungi are microorganisms that colonize inside the plant tissues such as roots, stems, leaves, flowers, or seeds without causing adverse effects on the host plant (Yadav 2018). Endophytes are useful for maintaining plant resistance to abiotic stresses such as increasing drought tolerance, plant disturbances during high and low temperatures, low $\mathrm{pH}$ environmental conditions, high salinity, and heavy metals pressure in the soil (Jalgaonwala et al. 2011; Sushma et al. 2021). Endophytes produced secondary metabolites that inhibit the growth of pathogenic bacteria, fungi and protozoa in humans, animals and plants (Martinez-Klimova et al. 2017). It has been reported that endophytic fungi can produce the same compounds as that of host. This can be seen from the results that reported the production of taxol by the endophytic fungus Taxomyces andreanae isolated from Taxus brevifolia (Monika et al. 2020). T. brevifolia is a rare plant, so the discovery of the ability of endophytic fungi to produce compounds having similarity to their hosts can be used as a strategy for the discovery of compounds having medicinal values without compromising the existence of endangered or rare species.

Previous studies reported that some compounds isolated from $C$. amboinicus endophytic fungi exhibited cytotoxic activities (Astuti et al. 2016; 2020; 2021b). It has been observed that the ability of endophytes in producing secondary metabolites was influenced by many factors including light exposure (Kim et al. 2014; Soliman and Raizada 2018). Light also affected production of Taxol and Baccatin III in the Taxus cuspidata cell culture (Fett-Neto et al. 1995). Exposing natural light to the fermentation of Eutypa linearis, an endophytic fungus obtained from the leaves of $C$. amboinicus also influenced the metabolite production and thus its bioactivity (Gemantari et al. 2021). Previous studies reported that an $\mathrm{N}$-containing substance isolated from endophytic fungus $A$. rasikravindrae isolated from the stem of $C$. amboinicus had cytotoxic activity against T47D and WiDr cancer cells (Astuti et al. 2021a). This study aimed to determine whether differences in fermentation conditions due to light exposure could influence secondary metabolites production of the fungal endophytic $A$. rasikravindrae and whether this also bring consequence on its bioactivity as antioxidant or anticancer.

\section{MATERIALS AND METHODS}

\section{Materials}

The reagents used in this study included ethyl acetate, chloroform, methanol, silica gel $\mathrm{F}_{254}$ purchased from Merck (Darmstadt, Germany). Potato Dextrose Agar (PDA) and Potato Dextrose Broth (PDB) were purchased from Oxoid
(Basingstoke, UK). Tris-HCl, quercetin dihydrate and 1,1Diphenyl-2-picrylhydrazyl (DPPH) purchased from SigmaAldrich (Saint Louis, USA). The cell culture growth media were DMEM (Dulbecco's Modified Eagle Medium) and RPMI (Roswell Park Memorial Institute), FBS (Fetal Bovine Serum, Gibco) as well as Fungizone and Penstrep (Sigma) media. Other cell culture materials were phosphate buffer saline (Sigma), trypsin-EDTA (Sigma), Doxorubicin, DMSO (Dimethyl Sulfoxide, Sigma), MTT (3- (4,5-dimethylthiazol-2-yl) -2,5-diphenyltetrazolium bromide, Sigma), and $\mathrm{HCl}$ pa (Merck).

\section{Fermentation and extraction of Arthrinium rasikravindrae}

The endophytic fungus was obtained from culture collection of Department of Pharmaceutical Biology, Faculty of Pharmacy, Universitas Gadjah Mada, Yogyakarta, Indonesia (Astuti et al. 2021a). The pure isolate of endophytic fungi (four plugs of 7 days old fungi grown on Potato Dextrose Agar) was cultured on Potato dextrose broth (PDB) containing $200 \mathrm{~mL}$ medium in $500 \mathrm{~mL}$ Erlenmeyer. The cultures were incubated in dark or exposed to natural light conditions, at room temperature, $25^{\circ} \mathrm{C}$ for 2 weeks, agitated at $120 \mathrm{rpm}$. The fermented cultures were filtered and the filtrate were extracted by liquid-liquid partition using ethyl acetate. The ethyl acetate (EtOAc) soluble layer was separated from the fermentation broth and then evaporated to dryness. The EtOAc extracts were kept at $4^{\circ} \mathrm{C}$ for further analysis.

\section{Antioxidant activities}

Radical scavenging activity was carried out using DPPH test with modifications (Alam et al. 2013). Preparation of DPPH test solution (2,2-diphenyl-1picrylhydrazyl) was carried out in dark conditions. Ten milligrams of the extract was dissolved in $10 \mathrm{~mL}$ of methanol and the concentration series was made at final concentration of $250,125,62.5,31.25,15.63 \mu \mathrm{g} / \mathrm{ml}$. Quercetin was used as positive control. One $\mathrm{mL}$ of sample or positive control solution, was mixed with $1 \mathrm{~mL}$ of 0.1 mM DPPH solution. The mixture was incubated for 30 minutes in dark conditions. The absorbance was measured at $517 \mathrm{~nm}$. Each treatment was replicated three times. Radical scavenging activity was analyzed based on \% of inhibition with the formula:

Inhibition $(\%)=1-\left(\frac{\text { Absorbance Sample }- \text { Absorbance Blank }}{\text { Absorbance Control }- \text { Absorbance Blank }}\right) \times 100 \%$

Where:

Absorbance Sample = absorbance extract/quercetin and DPPH solution

Absorbance Blank = absorbance extract in serial concentration and methanol

Absorbance Control $=$ absorbance methanol and DPPH solution

$\mathrm{IC}_{50}$ value is the concentration where DPPH as a free radical is reduced by $50 \%$ and analyzed based on the sample concentration plotted against \% inhibition at each concentration point. 


\section{Cytotoxic activities}

The cytotoxicity of the ethyl acetate extracts on cancer cells was performed using MTT assay (3-(4,5-dimethylthiazol-2-yl)-2,5-di-phenyltetrazolium bromide) against HeLa, MCF7, T47D, and WiDr cells (Ekowati et al. 2020). T47D, WiDr, and Hela cells were cultured in RPMI, MCF7 and Vero were cultured in DMEM. Vero cells were used as normal cell model. RPMI and DMEM were supplemented with $1 \%$ fungizone, $1 \%$ pen strep and $10 \%$ FBS. Cells at $80 \%$ confluence were detached using trypsin and harvested, seeded at a density of $5 \times 10^{3}$ cells/well. Cell suspension $(100 \mu \mathrm{L})$ was added to each well of 96-well plate and grown to $80 \%$ confluence in a humidified incubator at $37^{\circ} \mathrm{C}, 5 \% \mathrm{CO}_{2}$ for $24 \mathrm{~h}$. The media was discarded and replaced by adding new media containing various extract concentrations $(500,250,125,62.5,31.25 \mu \mathrm{g} / \mathrm{mL})$. Doxorubicin was used as positive control, medium only (without cells) were included as blank control. After $24 \mathrm{~h}$ incubation, the medium was removed and wells were washed with $1 \mathrm{X}$ warm PBS. Thereafter, $100 \mu \mathrm{L}$ of medium containing $0.5 \mathrm{mg} / \mathrm{ml}$ (MTT) solution was added to each well, and the plate was incubated for another additional $4 \mathrm{~h}$ at $37^{\circ} \mathrm{C}$. After that, $100 \mu \mathrm{L}$ of $10 \%$ sodium dodecyl sulfate$0.01 \mathrm{~N} \mathrm{HCl}$ were added to each well and incubated overnight at room temperature in dark conditions. The optical density was measured using a microplate reader (Biorad) at $595 \mathrm{~nm}$. All experiments were performed in triplicate.

For the experiment using combination of extract with Doxorubicin, the extract concentration used was $1 / 2 \mathrm{IC}_{50}$. Doxorubicin at the concentration of $1 / 2 \mathrm{IC}_{50}$ was added at different time points, overnight before, and concurrently with the addition of the extract.

The absorbance value (Abs) was determined and analyzed into \% cell viability as followed:

Cell Viability $(\%)=\frac{\text { Absorbance of treated cells }- \text { Absorbance of medium }}{\text { Absorbance of control untreated cells }- \text { Absorbance of medium }} \times 100 \%$

$\mathrm{IC}_{50}$ was calculated based on the plot of sample concentration versus $\%$ cell viability and the concentration value indicates $50 \%$ inhibition of cell growth.

\section{Secondary metabolites analysis}

Phytochemical analysis of ethyl acetate extract of endophytic fungi was conducted using thin-layer chromatography (TLC) and gas chromatography-Mass Spectrometry (GC-MS) analysis. TLC was performed with a stationary phase of Silica Gel $60 \mathrm{~F}_{254}$ (Merck) with a mobile phase of chloroform: ethyl acetate $(7: 3 \mathrm{v} / \mathrm{v})$. The TLC plate was observed under visible light, $\mathrm{UV}_{254}$, and $\mathrm{UV}_{366}$ light, as well as using anisaldehyde-sulfuric acid spray reagent detection followed by heating the plate at $105^{\circ} \mathrm{C}$ in the hot air oven until development of spots. Volatile compounds from the stem ethyl acetate extract of Coleus amboinicus, ethyl acetate extract of endophyte fungi in dark and exposed to natural light conditions were analyzed using GC-MS-QP2010 (Shimadzu, Tokyo, Jepang). Sample $(0.5 \mu \mathrm{L})$ dissolved in chloroform: methanol $(1: 1 \mathrm{v} / \mathrm{v})$ was injected into GC-MS capillary column cross bond $100 \%$ dimethylpolysiloxane $(30 \mathrm{~m} \mathrm{x}$ $0.25 \mathrm{~mm} \times 0,25 \mu \mathrm{m})$. Ion source temperature was $200^{\circ} \mathrm{C}$, injector temperature was $250^{\circ} \mathrm{C}$, and column temperature was set $100-250^{\circ} \mathrm{C}$, increased $10^{\circ} \mathrm{C} / \mathrm{min}$. Helium as carrier gas, column pressure of $100 \mathrm{kPa}$, flow rate of 1.33 $\mathrm{mL} /$ minute. The electron ionization(EI) of the mass detector at $70 \mathrm{eV}$. Identification of volatile compounds was performed using mass spectrum library data WILEY 7.LIB based on their retention time.

\section{Statistical analysis}

Data were analyzed statistically using One Way ANOVA test or Kruskal Wallis test (SPSS program version 16) depend on normality value and independent-sample ttest. Value of $\mathrm{p}<0.05$ was considered different significantly with $95 \%$ confidence level. The experiments were conducted triplicate and expressed as mean \pm standard deviation (SD).

\section{RESULTS AND DISCUSSION}

\section{Effect of light exposure on secondary metabolites production}

In this study, the fermentation culture treated at dark and natural light exposure was extracted using ethyl acetate, and then analyzed by TLC and GC-MS. Based on TLC data there were differences in phytochemical profiles between A. rasikravindrae extract both at dark and light exposure compared to stem extract (Figure 1). In addition, dark fermentation conditions showed more spots compared to light conditions as determined by anisaldehyde-sulfuric acid detection reagent $\left(R_{f} 0.6-0.9\right)$ and $\mathrm{UV}_{366}$ light $\left(R_{f} 0.55\right.$ 0.85 ). Light exposure was reported by some studies to have an effect on the metabolites produced (Fett-Neto et al. 1995; Avalos and Estrada 2010; Kim et al. 2014; Soliman and Raizada 2018).

In order to examine the volatile components within the extracts, GC-MS analysis was also conducted (Figure 2). The results showed that there was a compound present in all extracts, namely methyl octadec-9-enoate (Tables 1, 2 and 3). This compound was reported to have antifungal properties and correlate with antioxidant and antibacterial activities (Abubacker and Deepalakshmi 2013; Bittencourt et al. 2015). It is interesting to note that underexposure to natural light, there was additional compound, which was similar to the stem extract, namely methyl palmitate (hexadecanoic acid, methyl ester). In line with the TLC profiles, GC-MS analysis also indicated that more compounds were produced in dark fermentation conditions. The differences in some compounds present in dark and light condition as well as the retention times suggested that natural light affect metabolites production. This study similar to that reported by Soliman and Raizada (2018), which showed that light suppresses the genes that synthesize taxol production and induces the expression of opsin genes for dark green pigments in an endophytic fungus (Soliman and Raizada 2018). 
Table 1. The major chemical compounds of Coleus amboinicus stem ethyl acetate extract as analyzed by GC-MS

\begin{tabular}{lllccc}
\hline R. time & PA $(\%)$ & Structure name & SI & Molecular formula & MW (g/mol) \\
\hline 13.825 & 26.03 & $\begin{array}{l}\text { Hexadecanoic acid, methyl ester (CAS) methyl palmitate, methyl } \\
\text { hexadecanoic, methyl n-hexadecane }\end{array}$ & 96 & $\mathrm{C}_{17} \mathrm{H}_{34} \mathrm{O}_{2}$ & 270 \\
14.702 & 33.24 & $\begin{array}{l}\text { 9,12-Octadecadienoic acid (Z,Z)-, methyl ester (CAS) methyl } \\
\text { linoleate }\end{array}$ & 96 & $\mathrm{C}_{19} \mathrm{H}_{34} \mathrm{O}_{2}$ & 294 \\
14.742 & 40.74 & $\begin{array}{l}\text { 9-Octadecenoic acid, methyl ester (CAS) methyl octadec-9-enoate } \\
\text { 9-OT }\end{array}$ & $\mathrm{C}_{19} \mathrm{H}_{36} \mathrm{O}_{2}$ & 296 \\
\hline
\end{tabular}

Table 2. The major chemical compounds of ethyl acetate extract of Arthrinium rasikravindrae fermented in dark condition as analyzed by GC-MS

\begin{tabular}{lllccc}
\hline R. time & PA $(\%)$ & Structure name & SI & Molecular formula & MW (g/mol) \\
\hline 10.430 & 30.12 & 1,2-Ethanediol, 1-phenyl- (CAS) styrene glycol & 90 & $\mathrm{C}_{8} \mathrm{H}_{10} 0_{2}$ & 138 \\
10.610 & 27.62 & 1,2-Ethanediol, 1-phenyl- (CAS) styrene glycol & 88 & $\mathrm{C}_{8} \mathrm{H}_{10} 0_{2}$ & 138 \\
10.671 & 15.64 & 1,2-Ethanediol, 1-phenyl- (CAS) styrene glycol & 90 & $\mathrm{C}_{8} \mathrm{H}_{10} 0_{2}$ & 138 \\
13.314 & 25.02 & Rosifoliol & 82 & $\mathrm{C}_{15} \mathrm{H}_{24} 0_{2}$ & 220 \\
14.738 & 1.61 & 9-Octadecenoic acid, methyl ester (CAS) methyl octadec-9-Enoate & 97 & $\mathrm{C}_{19} \mathrm{H}_{36} \mathrm{O}_{2}$ & 296 \\
\hline
\end{tabular}

Table 3. The major chemical compounds of ethyl acetate extract of Arthrinium rasikravindrae fermented exposed to natural light as analyzed by GC-MS

\begin{tabular}{lllccc}
\hline R. time & PA $(\%)$ & Structure name & SI & Molecular formula & MW (g/mol) \\
\hline 18.926 & 13.96 & $\begin{array}{l}\text { 3,5-Dihydroxydecanoic acid .delta.-lactone, 2H-Pyran-2-one, } \\
\text { tetrahydro-4-hydroxy-6-pentyl- (CAS) 3,5-Dihydroo acid .delta.- } \\
\text { lactone }\end{array}$ & 95 & $\mathrm{C}_{10} \mathrm{H}_{18} \mathrm{O}_{3}$ & \\
22.108 & 46.05 & $\begin{array}{l}\text { Hexadecanoic acid, methyl ester (CAS) methyl palmitate, methyl } \\
\text { hexadecanoic, methyl n-hexadecane }\end{array}$ & 96 & $\mathrm{C}_{17} \mathrm{H}_{34} \mathrm{O}_{2}$ & \\
22.437 & 23.88 & $\begin{array}{l}\text { Hexadecanoic acid (CAS) Palmitic acid } \\
\text { 9-Octadecenoic acid, methyl ester (CAS) methyl octadec-9-enoate }\end{array}$ & 94 & $\mathrm{C}_{16} \mathrm{H}_{32} \mathrm{O}_{2}$ & 270 \\
$\mathrm{C}_{19} \mathrm{H}_{36} \mathrm{O}_{2}$ & 256
\end{tabular}

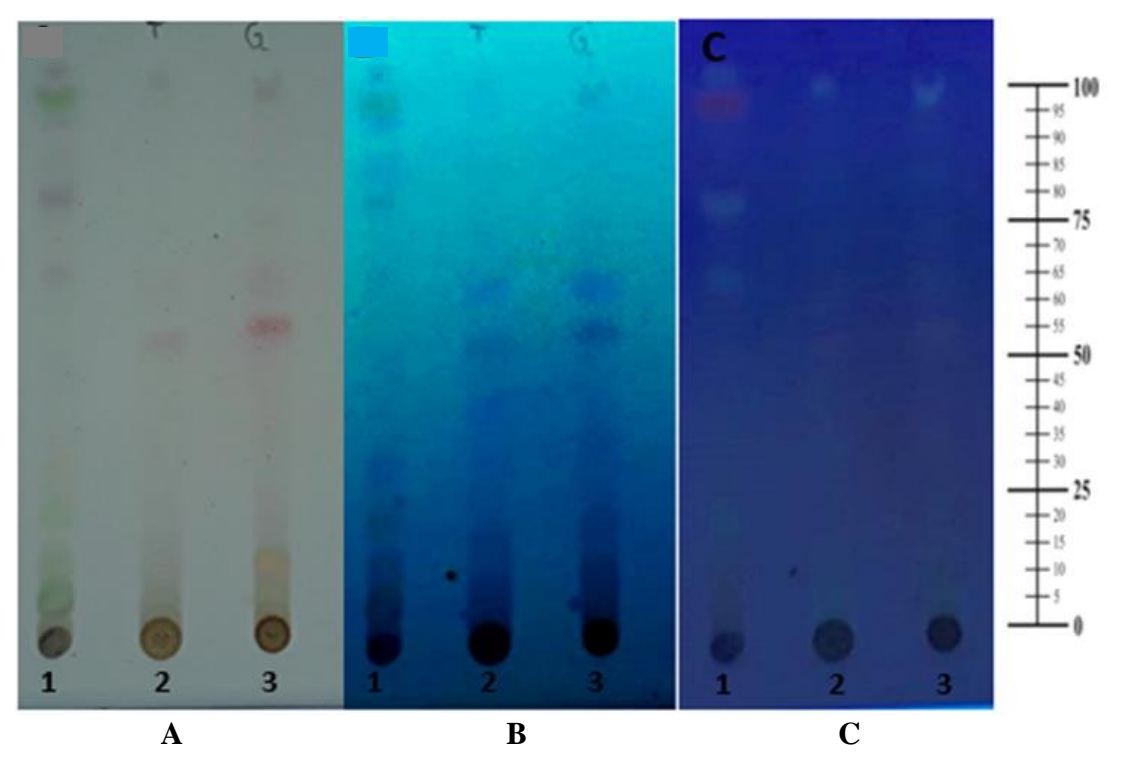

Figure 1. Thin Layer Chromatography (TLC) profiles of ethyl acetate extract of fermentation broth of Arthrinium rasikravindrae detected using anisaldehyde-sulphuric acid reagent (A) $\mathrm{UV}_{254}$ light (B) $\mathrm{UV}_{366}$ light (C) Stationary phase = Silica Gel $60 \mathrm{~F}_{254}$; mobile phase $=$ chloroform: ethyl acetate $(7: 3 \mathrm{v} / \mathrm{v}) .1$. Stem extract of $C$. amboinicus. 2 . Ethyl acetate extract of A. rasikravindrae exposed to light. 3. Ethyl acetate extract of A. rasikravindrae in dark condition 


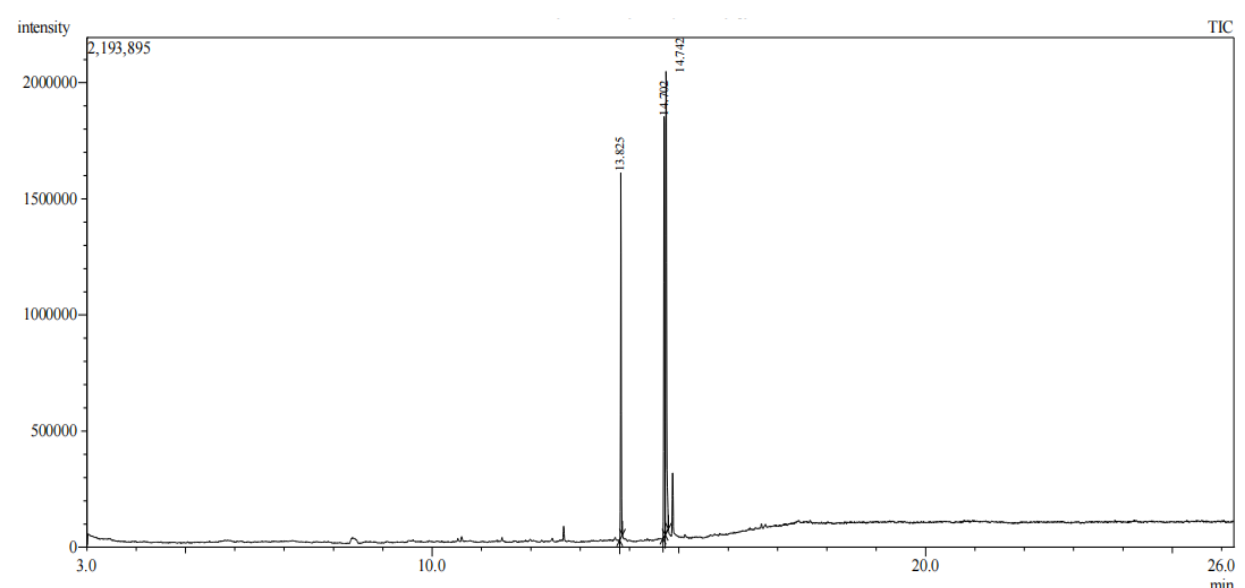

A

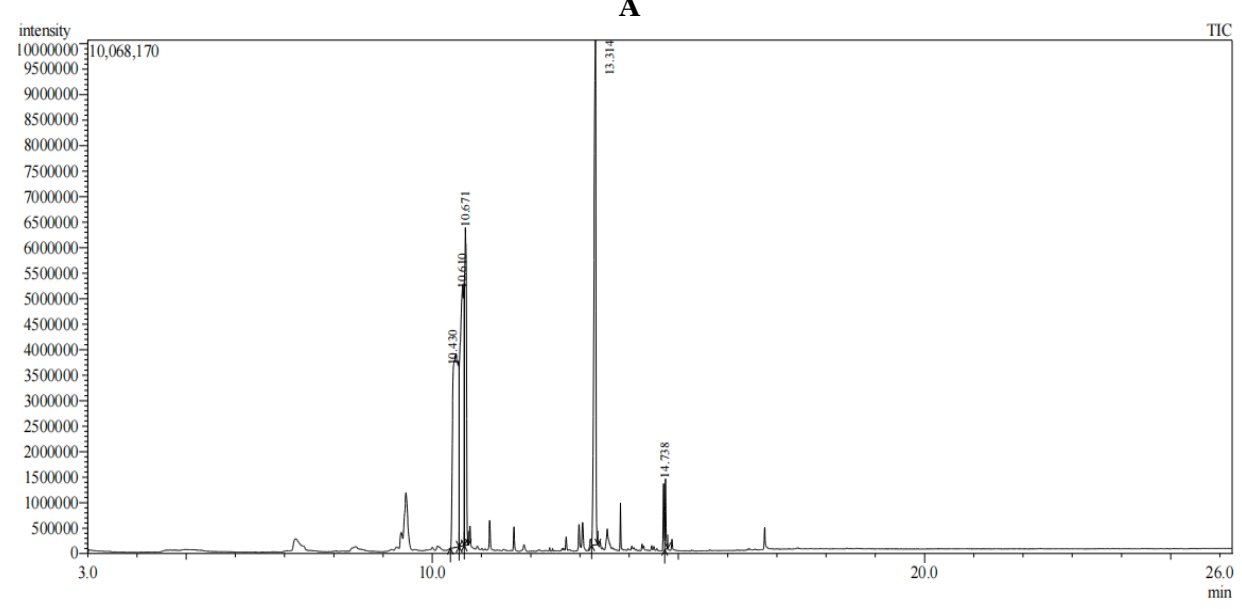

B

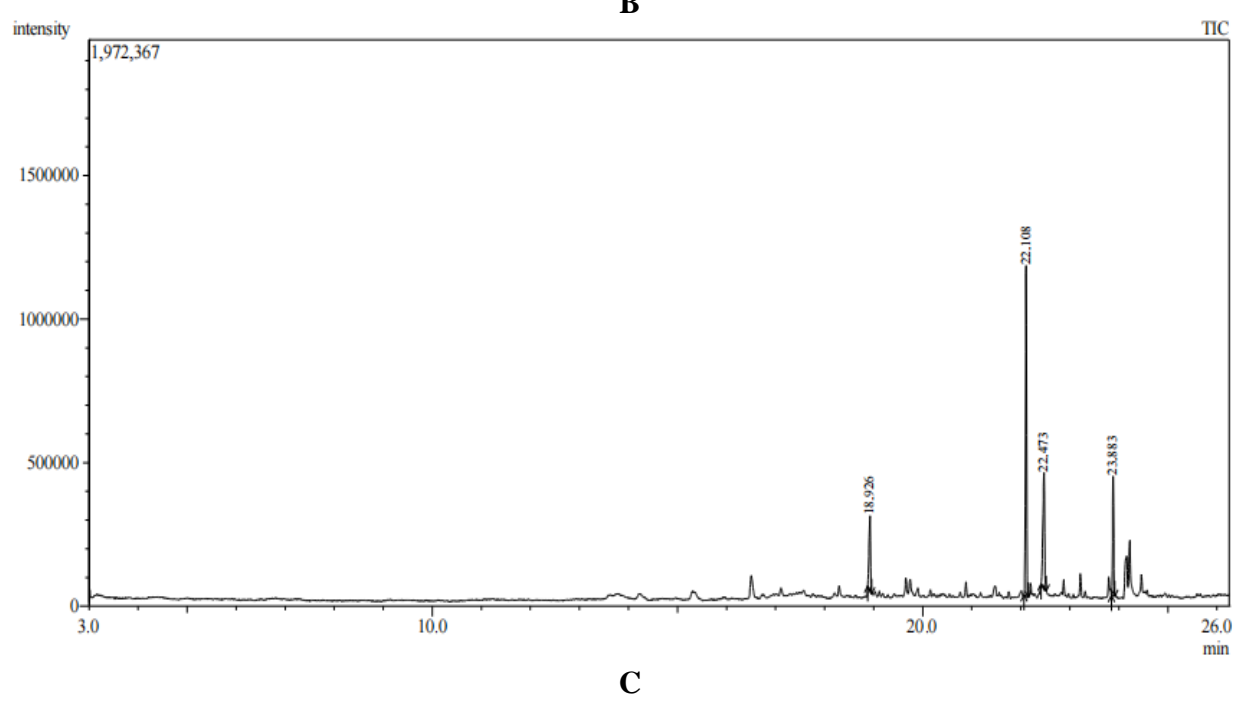

Figure 2. A. Gas Chromatography-MS Profile of Coleus amboinicus stem ethyl acetate extract, B. Arthrinium rasikravindrae fermented in dark condition, C. A. rasikravindrae fermented with natural light exposure

\section{Antioxidant activities}

This study attempts to examine whether the endophytic fungus $A$. rasikravindrae isolated from $C$. amboinicus also produced antioxidant compounds were conducted. It was found that the $A$. rasikravindrae fermented at dark conditions had $\mathrm{IC}_{50}$ of $66.36 \pm 0.53$ better than that fermented exposed to the natural light $(556.91 \pm 34.37)$
(Table 4). The antioxidant properties of dark fermentation extract were considered strong (50-100 $\mu \mathrm{g} / \mathrm{mL})$, while the extract exposed to light was categorized as weak (> 500 $\mu \mathrm{g} / \mathrm{mL}$ ) (Ansharullah et al. 2020). The extract from dark conditions mainly consists of styrene glycol, general flavoring agents used in foods, including condiments and seasonings (Arn and Acree 1998). The strong activity of 
the extract under dark conditions could be contributed by the presence of rosifoliol, which represented $25.02 \%$ of the extract. This compound was reported to have antioxidant activity (Rosa et al. 2007). The ability of endophytic fungus Arthrinium sp. to produce antioxidant was also reported by Pansanit and Pripdeeveech (2018) who found the antioxidant activity of its ethyl acetate extract with an $\mathrm{IC}_{50}$ value of $28.47 \mu \mathrm{g} / \mathrm{mL}$ as determined by DPPH test (Pansanit and Pripdeevech 2018). The differences in antioxidant properties of the extract under dark and light conditions could be contributed by the effect of light on metabolite production. According to some literature, light exposure could affect the genes that play a role in the biosynthesis of bioactive compounds such as the taxol by the endophytic fungus SSM001 and aurofusarin and trichothecene by Fusarium graminearum ( Kim et al. 2014; Soliman and Raizada 2018).

\section{Cytotoxic activities}

In this study, it was found that $A$. rasikravindrae isolated from $C$. amboinicus stem also exhibited cytotoxic activity. The fungi fermented under exposure to natural light produced compounds that were more potent than those in dark fermentation conditions. However, the level of cytotoxicity was considered weak $\left(\mathrm{IC}_{50}>100-1,000\right.$ $\mu \mathrm{g} / \mathrm{ml}$ ) (Ads 2020). $\mathrm{IC}_{50}$ extract obtained from fermentation with light exposure were $291.40 \pm 2.34 \mu \mathrm{g} / \mathrm{mL}$ on WiDr, $336.80 \pm 5.05 \mu \mathrm{g} / \mathrm{mL}$ on T47D, and $404.73 \pm 3.46 \mu \mathrm{g} / \mathrm{mL}$ on Hela cell lines (Table 5). The $\mathrm{IC}_{50}$ values of the extract obtained from dark fermentation could not be determined in this study since its $\mathrm{IC}_{50}>500 \mu \mathrm{g} / \mathrm{mL}$, the maximum concentration used in this study. Similarly, $\mathrm{IC}_{50}$ values of both extract from light and dark fermentation conditions could not be examined towards normal Vero cells (> 500 $\mu \mathrm{g} / \mathrm{mL})$.

The better activity of extract exposed to the light as compared to the dark conditions could be contributed from the major volatile compounds present. A hexadecanoic acid compound (methyl palmitate) which was present at $46.05 \%$ on light fermentation condition extract was shown to be a good adjuvant for Sorafenib therapy on hepatocellular carcinoma cells (Breeta et al. 2021). Another hexadecenoic acid, palmitic acid $(23.88 \%)$ compound was also reported to have cytotoxic activity (Harada et al. 2002). The results of the cytotoxic study indicated that ethyl acetate extract from the endophytic fungus $A$. rasikravindrae was also has the potential for further development. The potential of the endophytic fungi as a source of bioactive metabolites having chemotherapeutic values has been reviewed (Stierle and Stierle 2015). Several studies also have reported that endophytic fungus Arthrinium sp. had cytotoxic activity (Ebada et al. 2011; Bao et al. 2018; Su et al. 2020).

In this study, attempts to examine how the extract was capable of inducing cell death were determined by combining the extract obtained from light fermentation condition with doxorubicin. The combination treatment was carried out on WiDr which was found to have the best $\mathrm{IC}_{50}$ value. Extract at the concentration of $1 / 2 \mathrm{IC}_{50}$ was combined with doxorubicin at the concentration of $1 / 2 \mathrm{IC}_{50}$ which was added at two different time points. The data showed that adding the extract overnight after administration of doxorubicin resulted in more cell death compared to adding at the same time (Figure 3). The extract added overnight after doxorubicin treatment resulted in $15.42 \pm 0.76 \%$ of WiDr cell viability as compared to adding at the same time $(34.44 \pm 2.83 \%$ cell viability). The viability of combined sample added at different time points resulted in more cell death as compared to administration of doxorubicin or the extract alone. It has been observed that doxorubicin-induced WiDR cell cycle arrest in the S and G2/M phase (Utami et al. 2020). Considering the higher level of cell death due to different time points of administration of extract towards doxorubicin suggested that doxorubicin may induced cell cycle arrest which then be abrogated by the presence of extract. Additional experiment using flow cytometry analysis or other methods is needed to confirm this finding. Checkpoint at G2 phase is an attractive target for anticancer therapy. Abrogating this G2 checkpoint prevents the cells to repair DNA damage and forces them to enter mitotic catastrophe. Checkpoint inhibition has grown to be the target for novel drug development with some of them have been in phase I/II clinical trials (Bucher and Britten 2008).

Table 5. Cytotoxicity of Arthrinium rasikravindrae ethyl acetate extract under dark and light conditions, expressed as $\mathrm{IC}_{50}$ against several cancer cell lines

\begin{tabular}{lccc}
\cline { 3 - 4 } Cells & $\begin{array}{c}\text { Ethyl acetate } \\
\text { extract, dark } \\
\text { condition }\end{array}$ & $\begin{array}{c}\text { Ethyl acetate } \\
\text { extract, light } \\
\text { condition }\end{array}$ & Doxorubicin \\
\hline Hela & $>500$ & $404.73 \pm 3.46$ & $4.33 \pm 0.12$ \\
T47D & $>500$ & $336.80 \pm 5.05$ & $1.98 \pm 0.11$ \\
WiDr & $>500$ & $291.40 \pm 2.34$ & $2.52 \pm 0.14$ \\
MCF-7 & $>500$ & $>500$ & $3.30 \pm 0.21$ \\
Vero & $>500$ & $>500$ & $7.55 \pm 0.83$ \\
\hline
\end{tabular}

Note: All data are presented as mean \pm SD $(n=3) p<0.05$

Table 4. DPPH scavenging activity of Arthrinium rasikravindrae ethyl acetate extract under dark and light conditions, expressed as $\mathrm{IC}_{50}$ values

\begin{tabular}{ll}
\hline Samples & $\mathbf{I} \mathbf{C}_{\mathbf{5 0}}(\boldsymbol{\mu g} / \mathbf{m L})$ \\
\hline Ethyl acetate extract from fermentation broth under dark condition & $66.36 \pm 0.53^{*}$ \\
Ethyl acetate extract from fermentation broth exposed to natural light & $556.91 \pm 34.37 *$ \\
Quercetin & $1.365 \pm 0.022^{*}$ \\
\hline
\end{tabular}

Note: All data are presented as mean $\pm \operatorname{SD}(n=3) ; *$ statistically significant different $\mathrm{p}<0.05$ 


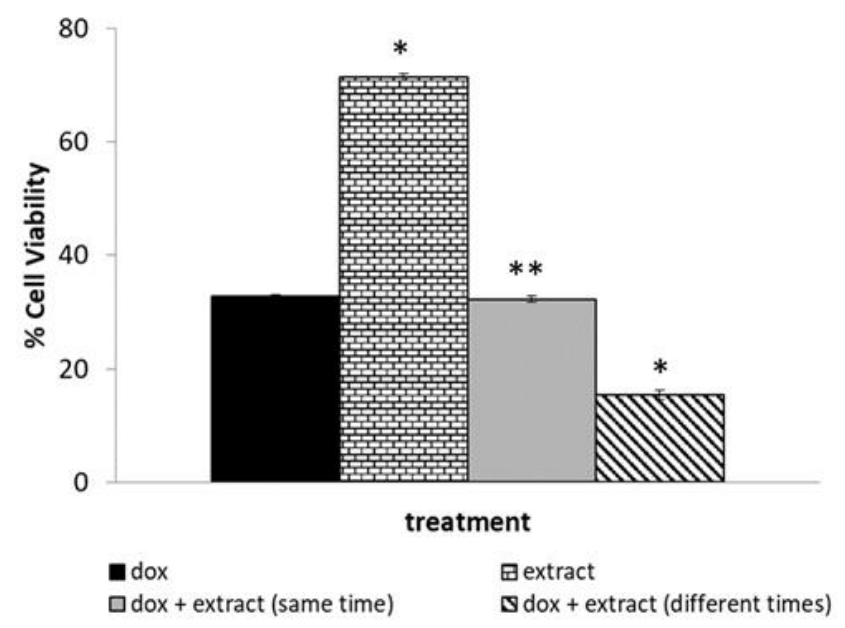

Figure 3. Cytotoxic combination test of Arthrinium rasikravindrae ethyl acetate extract from light fermentation condition with doxorubicin on WiDr cells, expressed as \% cell viability. * statistically significantly different with dox; **statistically no significant difference with dox. All data are expressed as mean \pm $\mathrm{SD}(\mathrm{n}=3) \mathrm{p}<0.05$

Doxorubicin is a cytostatic drug that is well known for its use in the treatment of various cancers (Lüpertz et al. 2010). However, due to its instability for oral administration and its side effect, doxorubicin is not the primary choice for colon cancer chemotherapy, although due to its cost-effectiveness, this agent is still considered a drug of choice (Sonowal et al. 2017). The mechanism of doxorubicin towards its pro-apoptotic effect is by disrupting the function of DNA and caused DNA damage. It is also mentioned that doxorubicin can intercalate into the DNA double helix, inhibiting topoisomerase II and cross-linked DNA strands (Gewirtz 1999). Doxorubicin initiated human colon cell cycle arrest, which can occur either at G0/G1 or G2 phase, and this mechanism of cell cycle induced arrest could be dependent or independent p53 (Lüpertz et al. 2010). The p53 is a transcriptional factor that can be activated by genotoxic stress. It regulates multiple cellular responses which are involved in cell cycle control, DNA repair, and apoptosis (Vousden and $\mathrm{Lu}$ 2002).

Based on the results of the present study, natural light had an effect on secondary metabolites production of the endophytic fungi Arthrinium rasikravindrae. The differences in secondary metabolites profiles influenced its bioactivity as antioxidant and anticancer.

\section{ACKNOWLEDGEMENTS}

Authors thank the Indonesian Ministry of Education and Culture for funding the research project under Gadjah Mada University (UGM) PDUPT Grant no 1764/UN1/DITLIT/DITLIT/PT/2020. The data were part of Andita Eltivitasari's master thesis. The authors declare that there are no conflicts of interest.

\section{REFERENCES}

Abubacker MN, Deepalakshmi T. 2013. In vitro antifungal potentials of bioactive compound methyl ester of hexadecanoic acid isolated from Annona muricata Linn. (Annonaceae) leaves. Biosci Biotechnol Res Asia 10 (2): 879-884. DOI: $10.13005 / \mathrm{bbra} / 1211$

Ads DE. 2020. Evaluation of cytotoxic effects of methanolic extract of Pergularia tomentosa growing wild in KSA. Asian Pac J Cancer Prev 21: 67-72. DOI: 10.22034/APJCP.2020.21. S2.67

Aisyah SI, Rusmiyati H, Sukma D, Damanik R, Nurcholis W. 2020. Analisis komparatif kandungan metabolit pada daun mutan tanaman Torbangun (Plectranthus amboinicus (Lour.) Spreng.). AGROSAINSTEK: Jurnal Ilmu dan Teknologi Pertanian 4 (1): 10-16. DOI:10.33019/agrosainstek [Indonesian]

Alam MN, Bristi NJ, Rafiquzzaman M. 2013. Review on in vivo and in vitro methods evaluation of antioxidant activity. Saudi Pharm J 21 (2): 143-152. DOI: $10.1016 /$ j.jsps.2012.05.002

Ansharullah A, Patadjai AB, Asranudin. 2020. Effect of microwave heating on the antioxidant activities and physicochemical properties of sea cucumber (Holothuria scabra) powder. Int J Sci Technol Res 9 (1): 331-334.

Arn H, Acree TE. 1998. Flavornet: A database of aroma compounds based on odor potency in natural products. Dev Food Sci 40: 27. DOI: 10.1016/S0167-4501(98)80029-0

Arumugam G, Swamy MK, Sinniah UR. 2016. Plectranthus amboinicus (Lour.) Spreng: Botanical, phytochemical, pharmacological and nutritional significance. Molecules 21 (4): 369 . DOI: 10.3390/molecules21040369

Astuti P, Erden W, Wahyono, Wahyuono S, Hertiani T. 2016. Pyrophen produced by endophytic fungi Aspergillus sp. isolated from Piper crocatum Ruiz and pav exhibits cytotoxic activity and induces s phase arrest in T47D breast cancer cells. Asian Pac J Cancer Prev 17 (2): 615-618. DOI: 10.7314/apjcp.2016.17.2.615

Astuti P, Pratoko DK, Rollando R, Nugroho GW, Wahyuono S, Hertiani T, Nurrochmad A. 2021a. Bioactivities of a major compound from Arthrinium rasikravindrae an endophytic fungus of Coleus amboinicus Lour. FABAD J Pharm Sci 46 (1): 23-29.

Astuti P, Rollando R, Pratoko DK, Wahyuono S, Nurrochmad A. 2021 b. Antimicrobial and cytotoxic activities of a compound produced by an endophytic fungus isolated from the leaves of Coleus amboinicus Lour. Int J Pharm Res 13 (1): 2632-2644. DOI: 10.31838/ijpr/2021.13.01.394

Astuti P, Rollando R, Wahyuono S, Nurrochmad A. 2020. Antimicrobial activities of isoprene compounds produced by an endophytic fungus isolated from the leaves of Coleus amboinicus Lour. J Pharm Pharm Res 8: 280-289.

Avalos J, Estrada AF. 2010. Regulation by light in Fusarium. Fungal Genet Biol 47 (11): 930-938. DOI: 10.1016/j.fgb.2010.05.001

Bao J, Zhai H, Zhu K, Yu JH, Zhang Y, Wang Y, Jiang CS, Zhang X, Zhang Y, Zhang H. 2018. Bioactive pyridone alkaloids from a deepsea-derived fungus Arthrinium sp. UJNMF0008. Mar Drugs 16 (5): 174. DOI: $10.3390 / \mathrm{md} 16050174$

Bhatt P, Joseph GS, Negi PS, Varadaraj MC. 2013. Chemical composition and nutraceutical potential of Indian Borage (Plectranthus amboinicus) stem extract. J Chem 320329: 1-7. DOI: $10.1155 / 2013 / 320329$

Bittencourt MLF, Ribeiro PR, Franco RLP, Hilhorst HWM, de Castro RD, Fernandez LG. 2015. Metabolite profiling, antioxidant, and antibacterial activities of Brazilian propolis: Use of correlation and multivariate analyses to identify potential bioactive compounds. Food Res Int 76: 449-457. DOI: 10.1016/j.foodres.2015.07.008

Breeta RDIE, Grace VMB, Wilson DD. 2021. Methyl Palmitate-A suitable adjuvant for Sorafenib therapy to reduce in vivo toxicity and to enhance anti-cancer effects on hepatocellular carcinoma cells. Basic Clin Pharmacol Toxicol 128 (3): 366-378. DOI: 10.1111/bcpt. 13525

Bucher N, Britten CD. 2008. G2 checkpoint abrogation and checkpoint kinase-1 targeting in the treatment of cancer. Br J Cancer 98 (3): 523528. DOI: $10.1038 /$ sj.bjc. 6604208

Damanik R. 2009. Torbangun (Coleus amboinicus Lour): A Bataknese traditional cuisine perceived as lactagogue by Bataknese lactating women in Simalungun, North Sumatera, Indonesia. J Human Lactation 25 (1): 64-72. DOI: 10.1177/0890334408326086 
Damanik RM, Kustiyah L, Hanafi M, Iwansyah AC. 2017. Evaluation lactogenic activity of ethyl acetate fraction of torbangun (Coleus amboinicus L.) leaves. IOP Conf Ser: Earth Environ Sci 101: 012007. DOI: 10.1088/1755-1315/101/1/012007

Ebada SS, Schulz B, Wray V, Totzke F, Kubbutat M, Müller W, Hamacher A, Kassack M, Lin W, Proksch P. 2011. Arthrinins A-D: Novel diterpenoids and further constituents from the sponge-derived fungus Arthrinium sp. Bioorg Med Chem 19 (15): 4644-4651 DOI: 10.1016/j.bmc.2011.06.013

Ekowati N, Mumpuni A, Ratnaningtyas NI, Maharning AR. 2020 Compounds detection and inhibition activity of chloroform and ethyl acetate extracts of Schizophyllum commune on some cancer cell types. Biodiversitas 21 (12): 5865-5871. DOI: 10.13057/biodiv/d211251

Fett-Neto AG, Pennington JJ, DiCosmo F. 1995. Effect of white light on taxol and baccatin III accumulation in cell cultures of Taxus cuspidato Sieb and Zucc. J Plant Physiol 146 (5): 584-590. DOI: 10.1016/S0176-1617(11)81918-8

Gemantari BM, Romadhonsyah F, Nurrochmad A, Wahyuono S, Astuti P. 2021. Bioactivity screening of endophytic fungus Eutypa linearis isolated from Coleus amboinicus (Lour.). Indones J Pharm 32 (1): 8695. DOI: $10.22146 /$ ijp. 1077

Gewirtz D. 1999. A critical evaluation of the mechanisms of action proposed for the antitumor effects of the anthracycline antibiotics adriamycin and daunorubicin. Biochem Pharmacol 57 (7): 727-741. DOI: 10.1016/S0006-2952(98)00307-4

Harada H, Yamashita U, Kurihara H, Fukushi E, Kawabata J, Kamei Y. 2002. Antitumor activity of palmitic acid found as a selective cytotoxic substance in a marine red alga. Anticancer Res 22(5): 2587 2590.

Hasibuan PA Z, Sitorus P, Satria D, Sibuea RD. 2019. Antioxidant properties and cytotoxic activity of ethyl acetate fraction of Plectranthus amboinicus (Lour.) Spreng. Leaves on HeLa and T47D Cell Lines. Indones J Cancer Chemoprev 10 (1): 37-45. DOI: 10.14499/indonesianjcanchemoprev10iss1pp37-45

Jalgaonwala RE, Mohite BV, Mahajan RT. 2011. A review: Natural products from plant-associated endophytic fungi. J Microbiol Biotechnol Res 1 (2): 21-32.

Kim H, Son H, Lee YW. 2014. Effects of light on secondary metabolism and fungal development of Fusarium graminearum. J Appl Microbiol 116 (2): $380-389$. DOI: $10.1111 / \mathrm{jam} .12381$

Lüpertz R, Wätjen W, Kahl R, Chovolou Y. 2010. Dose- and timedependent effects of doxorubicin on cytotoxicity, cell cycle and apoptotic cell death in human colon cancer cells. Toxicol 271 (3): 115-121. DOI: 10.1016/j.tox.2010.03.012

Mahran YF, Badr AM, Aldosari A, Bin-Zaid R, Alotaibi HN. 2019 Carvacrol and Thymol Modulate the Cross-Talk between TNF- $\alpha$ and IGF-1 Signaling in Radiotherapy-Induced Ovarian Failure. Oxidative Med Cell Longevity 3173745: 1-10. DOI: 10.1155/2019/3173745

Martinez-Klimova E, Rodríguez-Peña K, Sánchez S. 2017. Endophytes as sources of antibiotics. Biochem Pharmacol 134: 1-17. DOI: 10.1016/j.bcp.2016.10.010

Monika, Singh RK, Shrivastava A, Yadav A, Srivastava AK. 2020. 8 Endophytic bacteria as a source of bioactive compounds. In: Kumar A, Singh VK (eds) Microbial Endophytes. Woodhead Publishing. DOI: $10.1016 / \mathrm{B} 978-0-12-818734-0.00008-5$

Pansanit A, Pripdeevech P. 2018. Antibacterial secondary metabolites from an endophytic fungus, Arthrinium sp. MFLUCC16-1053 isolated from Zingiber cassumunar. Mycology 9 (4): 264-272. DOI: $10.1080 / 21501203.2018 .1481154$
Pinheiro PF, Costa AV, de Assis Alves T, Galter IN, Pinheiro CA, Pereira AF, Oliveira CMR, Fontes MMP. 2015. Phytotoxicity and cytotoxicity of essential oil from leaves of Plectranthus amboinicus, carvacrol, and thymol in plant bioassays. J Agric Food Chem 63 (41): 8981-8990. DOI: $10.1021 /$ acs.jafc.5b03049

Quiroga PR, Asensio CM, Nepote V. 2015. Antioxidant effects of the monoterpenes carvacrol, thymol and sabinene hydrate on chemical and sensory stability of roasted sunflower seeds. J Sci Food Agric 95 (3): 471-479. DOI: $10.1002 /$ jsfa.6744

Rosa A, Deiana M, Atzeri A, Corona G, Incani A, Melis MP, Appendino G, Dessì MA. 2007. Evaluation of the antioxidant and cytotoxic activity of arzanol, a prenylated $\alpha$-pyrone-phloroglucinol heterodimer from Helichrysum italicum subsp. microphyllum. Chemico-Biol Interact 165 (2): 117-126. DOI: 10.1016/j.cbi.2006.11.006

Rzepczynska IJ, Foyouzi N, Piotrowski PC, Celik-Ozenci C, Cress A, Duleba AJ. 2011. Antioxidants induce apoptosis of rat ovarian thecainterstitial cells. Biol Reprod 84 (1): 162-166. DOI: 10.1095/biolreprod.110.087585

SA Rifki SM, Said Hassane SO, Haid S, Bakkouche K, Kribii A, Kribii A. 2019. Phytochemical study and evaluation of the antioxidant activity of extracts of Plectranthus aromaticus originating in the island of great Comoros. J Pharm Pharm 6 (2): 83-88. DOI: 10.15436/23771313.19.2582

Salganik RI. 2001. The benefits and hazards of antioxidants: controlling apoptosis and other protective mechanisms in cancer patients and the human population. J Am Coll Nutr 20 (5 Suppl): 464S-472S. DOI: 10.1080/07315724.2001.10719185

Sinha N, Dabla PK. 2015. Oxidative stress and antioxidants in hypertension-a current review. Curr Hypertens Rev 11 (2): 132-142. DOI: $10.2174 / 1573402111666150529130922$

Soliman SSM, Raizada MN. 2018. Darkness: A crucial factor in fungal taxol production. Front Microbiol 9: 353. DOI: 10.3389/fmicb.2018.00353

Sonowal H, Pal PB, Wen JJ, Awasthi S, Ramana KV, Srivastava SK. 2017. Aldose reductase inhibitor increases doxorubicin-sensitivity of colon cancer cells and decreases cardiotoxicity. Sci Rep 7: 1-14. DOI: 10.1038/s41598-017-03284-w

Stierle AA, Stierle DB. 2015. Bioactive secondary metabolites produced by the fungal endophytes of conifers. Nat Prod Commun 10 (10): 1671-1682. DOI: $10.1177 / 1934578 X 1501001012$

Su XZ, Tang JW, Hu K, Li XN, Sun HD, Puno PT. 2020. Arthrinins E-G, Three Botryane Sesquiterpenoids from the Plant Endophytic Fungus Arthrinium sp. HS66. Nat Prod Bioprospecting 10 (4): 201-207. DOI: 10.1007/s13659-020-00248-y

Sushma, Verma RK, Thakur S, Singh H, Kapur D. 2021. Chapter 6-The role of fungi in abiotic stress tolerance of plants. In: Sharma VK, Shah MP, Parmar S, Kumar A (eds) Fungi Bio-Prospects in Sustainable Agriculture, Environment and Nano-Technology. Academic Press. DOI: 10.1016/B978-0-12-821394-0.00006-8

Utami DT, Nugraheni N, Jenie RI, Meiyanto E. 2020. Co-treatment of brazilein enhances cytotoxicity of doxorubicin on WiDr colorectal cancer cells through cell cycle arrest. Indones Biomed J 12 (4): 376383. DOI: 10.18585 /inabj.v12i4.1293

Vousden K, Lu X. 2002. Live or let die: the cell's response to p53. Nat Rev Cancer 2: 594-604. DOI: 10.1038/nrc864

Yadav AN. 2018. Biodiversity and biotechnological applications of hostspecific endophytic fungi for sustainable agriculture and allied $\begin{array}{llllll}\text { sectors. Acta Sci Microbiol } 1 & \text { (5): 1-5. DOI: }\end{array}$ 10.31080/ASMI.2018.01.0044 